International Journal of English Literature and Social Sciences
Vol-6, Issue-5; Sep-Oct, 2021

Peer-Reviewed Journal

\title{
Exciting New Technologies for a Green Future
}

\author{
Dr. Priyanka M.G.
}

Tumakuru, Karnataka, India

Received: 15 Aug 2021; Received in revised form: 15 Sep 2021; Accepted: 22 Sep 2021; Available online: 30 Sep 2021

(C2021 The Author(s). Published by Infogain Publication. This is an open access article under the CC BY license

(https://creativecommons.org/licenses/by/4.0/).

\begin{abstract}
New technologies refer to two emerging as well as booming concepts like Green technology and Green Marketing. Green technology means the technology which is environmentally friendly developed and used in such a way so that it does not disturb our environment and conserve natural resources. Green technology is referred to as environmental technology and clean technology. Unlike the technological ways in recent decades green technology is almost material science-based. Relying on the availability of alternative sources of energy.
\end{abstract}

Keywords—Green Future, Green technology, Green Marketing, Green Computing, Solar Energy.

\section{INTRODUCTION}

The purpose of this technology is to reduce global warming as well as the Greenhouse Effect. Its main aim is to find ways to create new technologies in such a way that they do not damage or deplete the planet's natural resources. It also expresses less harm to human, animal, and plant health. With the help of reducing pollution which shall improve the cleanliness as well. Today developed as well as developing countries are turning to green technology to secure the environment from negative impacts by adopting green technology wisely. With the implementation of Green technology, the earth can fight against environmental pollution and other various harmful things.

\section{Importance of Green Technology in Today's World}

In today's world, using green technology is very significant. It is important to be aware of what's happening around the world. Today's technology and conveniences are more focused on making luxuries available to more people. The Ugly Side of this is the products of new technologies are harming our environment. This raises the importance of using green technology all the more for using green technology industries and regulatory bodies are already taking steps in the right direction. By using green technology one can make the effort to help the environment heal. Developing a plant community, making less packaging materials, using environmentally friendly machines are just a few examples. Implementing green technology should become not only important but mandatory too. In the coming years with the earth's real energy resources depleting fast we have to rely on alternative sources of energy.

Green technology encourages the concept of cleanliness, freshness as well as promotes new dimensions. After understanding the importance of green technology, now we have to understand how green technology has been adopted in the industries.

Several developed countries all across the world are already encouraging green technology in their industries. Billions are being invested in new wing projects and Biomass plants. State-owned Enterprises and private sectors are motivated to develop the green technology industry, for example, wind turbine manufacturers and wind developers are already using green technology in power generation. Following are the few examples where Green technology is being implemented effectively in countries like China and parts of Europe.

1. Wastewater Treatment

2. Elimination of Industrial emissions

3. Recycling and Waste Management

4. Self-sufficient buildings

5. Waste-to-Energy 
6. Generation of Energy from the waves

7. Vehicles that do not emit gases

8. Harnessing Solar energy

9. Vertical gardens and farms

10. Natural gas boilers

The solar power industry is growing at an astonishing speed and aims to achieve enough solar capacity and use green technology in the industry. There is another example where we can see, green technology has been adopted and that is Green Computing referring to environmental and sustainable computing. Today's focus is shifting towards designing, manufacturing using, and disposing of computers and other electronic devices efficiently and effectively with minimal or no impact on the environment. More attention is being given to the recyclable and biodegradable dependability of obsolete products and industrial wastes. Using the Green technology industry is on the rise as consumers around the world, as well as many car manufacturers, are actively involved in developing green technology that can be applied to their products. Green technology in the industry will influence a lot on the development as almost everyone seems to realize the harmful effects of Greenhouse gases and Global warming on the environment.

\section{Goals of Green technology}

This picture talks about the goals or functions of green technology. They reduce (fuels, waste, energy consumptions, etc.), recycling (of paper, plastic, cans, batteries, clothing, etc.), renewing (renewing energy such as wind energy, water energy, solar energy, bio-fuel, Sewage water, etc.) Refuse (the use of plastic bags) and responsibility.

The Objective of green technology that is intended to achieve first is Sustainability. Sustainability means meeting the needs of society in a way that can continue indefinitely in the future without damaging or depleting natural resources. In short meeting present needs without compromising the ability of future generations to meet their own needs. Another major goal is cradle-to-cradle design the major what you call the impact of green technology will be attending the cradle to Grave cycle of manufacturing products, by creating products that can be fully reclaimed or reused. Another goal is source reduction. Reducing waste and pollution by changing the patterns of production and consumption. Another goal is Innovation that is developing alternative technologies where fossil fuel or chemical-intensive agriculture has been demonstrated to damage health and the environment. Another goal is Viability. That means creating a center of economic activity around technologies and products that benefit the environment speeding their implementation and creating new careers that truly protect the planet. Several recent developments coming from the high-tech sector are the result of the anxiety revolving around green technology and making environmentally friendly machines. As we know computers are hard to recycle and or rarely recycled as today's computers are made with a considerable amount of lead, cadmium brominated fire retardants, and plastics that can lead to toxic breakdown products.

Green computers or Green Computing refers to encouraging environmentally sustainable computing, it involves the practice of designing, manufacturing, using, and disposing of computers and associated subsystems effectively and efficiently with almost no impacts on the environment. Research is still going on into the key areas in making green computers as energy-efficient as possible. Efficient computer technologies are being developed to promote them as environmentally friendly machines. Computers and related types of equipment have been responsible for much of the global warming as amongst other reasons. Sophisticated power savers, hibernation modes, and laptops just take minute nips in energy rather than guzzling from the plug. The extensive adoption of liquid crystal displays has given way to substantial savings by replacing less efficient cathode-ray tube technology. Green computers promise to be completely carbon neutral in coming years with means reduced emissions, ideas of solar power work stations are already floating which will cut down on annual electricity costs through more energyefficient equipment and operations. The fast-paced technological world of today sure has a green lining not only with these environmentally friendly machines saving everyone's money, but they will also take a long way to protect our precious planet.

\section{THE CONCEPTS OF GREEN TECHNOLOGY}

Wind energy is called pure green technology. The wind is atmospheric air in motion, these are caused by solar energy but these are not the direct form of solar energy, it is an indirect form of solar energy because they are created not only by the sun's uneven heating of the atmosphere and also due to the irregular surface of the earth and Earth's rotation. That also plays a part in the creation of winds. So this wind flows and this motion energy of the wind is harvested by the modern wind turbine which is used to produce electricity how does wind turbine convert this energy in winds into electricity? wind the turbine converts the kinetic energy of the winds into mechanical power because of the rotation of the turbine which is mechanical power. This mechanical power can be 
used for specific tasks, for example, there are simple tasks like grinding the grains, pumping water, or a generator that can convert this mechanical power into electricity to power homes, businesses, schools, etc. The force of the wind that makes these turbine blades spin and the kinetic energy of the wind is converted into mechanical power by turning the blades and this energy is tapped or harvested and with the help of a generator is converted into electricity. A wind farm is a large land in which many are wind turbines installed. It is used for the large-scale production of electricity because when there are so many wind turbines the whole output of these wind turbines is harvested and are coupled together to get electricity on a commercial scale.

\section{Pros of Green Technology:}

\section{Purifying of Water:}

Green technology purifies water. The scarcity of pure drinking water is a major concern. Through the use of various technologies, a lot of campaigns have been successful in providing people with clean drinking water.

\section{Recycling:}

Green technology helps manage and recycle waste material. It allows it to be used for beneficial purposes. This technology is used for waste management, waste incineration, and more. A lot of recyclable material has allowed individuals to create plant fertilizer, sculptures, fuel, and even furniture.

\section{Purifying the Air:}

Dealing with carbon emissions is another focus. While the human race is improving in terms of various technologies. Automobiles, factories, etc. are emitting a lot of carbon that is detrimental to the planet. Green technology helps to reduce carbon emissions and purify the air. This allows people and other living things to breathe properly.

\section{Conserving Energy:}

Energy is being conserved through the use of such technology. Alternatives to devices that use a lot of electricity or fuel are being introduced to the public. The use of electric cars is on the rise, especially in the UK. People using environment-friendly devices and appliances are encouraged. While installation of such devices, namely solar panels, might be expensive for some people but the benefits it offers with regards to reducing bill expenses are tremendous in long term.

\section{Rejuvenating Ecosystems:}

Green or Clean technology is also being used to breathe life into ecosystems that have sustained a lot of damage due to human involvement. Through the use of this technology, trees are replanted, waste is managed and recycled. This ensures that the affected ecosystem can start again, and this time remains conserved. This helps to ensure that a lot of plant and animal species don't go extinct.

The Earth needs protection and green technology can help in providing exactly that to the planet we all depend upon to live.

\section{CONS OF GREEN TECHNOLOGY}

1. Expensive to Implement.

2. It is very challenging to spread awareness extensively about Green technology.

3. There are no known alternative chemical or raw material inputs.

4. There is no known alternative processing technology.

5. No guarantee about performance impacts.

6. Lack of human resources and skills.

\section{GREEN MARKETING OR ECO MARKETING}

Green marketing is making a product and selling those products which are environmentally friendly, which are reusable, recyclable, and easily disposable, and so on. Green marketing also refers to the selling of products or services by highlighting their environmental benefits. It can also be called eco-marketing or environmental marketing, and consumers recognize such brands by terms like 'organic,' 'eco-friendly,' 'recyclable,' or 'sustainable'. The term green marketing gained prominence in the late 1980s and early 1990s. The concept of Green marketing appeared as the after-effect of human's negative impact on our planet. Brands illustrate how they change their missions and practices from revenue driven to environmentally aware through business processes that have minimal impact on the environment.

It is a process of selling products and services based on their environmental benefits. Such products or services may be environmentally friendly or produced and packaged in an eco-friendly way.

- Green referring to just recyclable or decomposable materials.

- Green Marketing = Corporate Social Responsibility.

- Green and sustainability concepts are incompatible with modern marketing. 
- Green reflects purity that is purity in quality and dealings.

- Natural resources are limited and human wants are unlimited. It is important to utilize natural resources efficiently and effectively without wasting and achieving organizational goals. This can be made possible only by utilizing green marketing.

- Green Marketing is a new paradigm in the marketing literature.

- Green Marketing is a holistic approach towards integrating marketing within the pillars of sustainable development.

- Green Marketing is not simply a separate path but is the parallel approach to marketing like Corporate Social Responsibility (CSR).

\section{IMPORTANCE AND NEED OF GREEN MARKETING}

\section{Green marketing a need to Today}

It is well known that increasing production and business activities are polluting the natural environment of the world. As resources are limited and human wants are unlimited. Marketers must use resources efficiently so that organizational objectives are achieved but not at the cost of noninterest among people around the world regarding the protection of the natural environment. People are getting more concerned about the environment. As a result of this, the term green marketing has emerged. Hence marketers are feeling their responsibility towards protecting our environment and which in turn signifies the importance of green marketing.

Not only marketers but consumers should also have concerned about the environment and consumers are also changing their behavioral patterns. Nowadays individual as well as industrial consumers are becoming more concerned about environment-friendly products. They are using green products which are produced through green technology.

\section{Importance of Green marketing}

1. Protection of Environment

2. Public Health

3. Corporate image

4. Competitive Advantages

5. Educating Customer

6. Responsible Corporate Citizens

\section{Advantages of Green marketing}

- Energy Savings

- Slowing down Global warming

- Reduction of Air Pollution

- Less Soil Pollution

- Less Water Pollution

- Reduction in Plastic Pollution

- Green-tech may save natural resources

- May allow us to feed more people on a global scale

- May protect the poorest amongst us

- Waste reduction

- Effective Recycling

- Sustainable Energy Production

- New Business opportunities

- May strengthen a company's brand value

- Tax Benefits

\section{Disadvantages of Green marketing}

- High R\&D Costs

- High implementation Costs

- Green Technology is still immature

- Technical issues

- Implementation will take many years

- High Product costs

- Lack of knowledge of the general public

- Some companies may not survive the competition

- Job losses

- A sophisticated regulatory framework required

- Everything that is labeled as green is not green

The global Green Technology and Sustainability market size is expected to grow from USD 11.2 billion in 2020 to USD 36.6 billion by 2025, at a Compound Annual Growth Rate (CAGR) of $26.6 \%$ during the forecast period. The increasing awareness related to environmental concerns and the growing concerns and the increasing number of consumers and industrial interest towards the use of clean energy resources are driving the adoption of green technology and sustainability solutions and services in the market (According to Global Forecast to 2025). 


\section{CONCLUSION}

Global investment in green technology has been increasing by almost $20 \%$ over the last few years in different sectors like energy, innovation, and manufacturing. With more pressing environmental problems across the world like energy shortages, global warming, pollution, rising urban population, and others. And also Individuals, small and big companies, and countries are looking into the future to see how greener technologies can be adapted in which can help to change the world.

Finding a way to curb our huge reliance on fossil fuels and reduce pollution depends on how we develop new green technology and more eco-friendly solutions. We need alternative and more efficient solutions to shape the future which will help in conserving our precious environment for our upcoming generations.

\section{REFERENCES}

[1] Bright Green Future, Gregory Schwartz, First Edition 2021, Design Publishing.

[2] https://www.investopedia.com/terms/g/green tech.as $\mathrm{p}$

[3] https://www.green-technology.org/

[4] https://tecamgroup.com/10-examples-of-greentechnology/

[5] https://www.electropages.com/blog/2019/09/what-isgreen-technology

[6] https://emagazine.com/an-introduction-to-greentechnology/

[7] https://walterschindler.com/7-green-technologyexamples/

[8] https://www.green-technology.org/green-technologywhat-is-it/

[9] https://tecamgroup.com/10-examples-of-greentechnology/

[10] https://www.research-ingermany.org/en/infoservice/newsletter/newsletter2019/june-2019/green-technology-for-a-sustainableeconomy_infocus html 